\title{
"OURS IS A COURT OF PAPERS": EXPLORING SCOTLAND AND THE BRITISH ATLANTIC WORLD USING THE SCOTTISH COURT OF SESSION DIGITAL ARCHIVE PROJECT
}

\author{
DIGITAL HUMANITIES SPECIAL FEATURE
}

James P. Ambuske, The Fred W. Smith National Library for the

Study of George Washington at Mount Vernon

ABSTRACT

This essay describes the Scottish Court of Session Digital Archive Project (SCOS), a multi-institutional collaborative research initiative into Early America and the British Atlantic world. Developed by the digital scholarship team at the University of Virginia Law Library, in partnership with colleagues at the University of Edinburgh, SCOS explores everyday life in the eighteenth and early nineteenth centuries through Session Papers, the printed documents submitted to Scotland's supreme civil court during litigation. The project provides scholars, genealogists, and the public with openaccess digital copies of Session Papers held by the UVA Law Library, the Library of Congress, and other institutional partners. By digitizing these documents, contextualizing them with comprehensive metadata, and providing users with interpretative entry points, SCOS is designed to foster new research on this formative period of Scottish, British, and American history.

Keywords: Scotland; America; Atlantic World; $18^{\text {th }}$ century; $19^{\text {th }}$ century; court records; digital humanities; digitization 
The Scottish Court of Session Digital Archive Project (SCOS) is a multi-institutional collaborative research initiative into Early America and the British Atlantic world. Developed by the digital scholarship team at the University of Virginia Law Library, in partnership with colleagues at the University of Edinburgh, SCOS explores everyday life in the eighteenth and early nineteenth centuries through Session Papers, the printed documents submitted to Scotland's supreme civil court during litigation. The project provides scholars, genealogists, and the public with open-access digital copies of Session Papers held by the UVA Law Library, the Library of Congress, and other institutional partners. By digitizing these documents, contextualizing them with comprehensive metadata, and providing users with interpretative entry points, SCOS is designed to foster new research on this formative period of Scottish, British, and American history. ${ }^{1}$

SCOS's origins lay in the UVA Law Library's acquisition of a Session Papers collection nearly forty years ago. In the mid-1980s, the library purchased 58-linear feet of these documents from a San Francisco rare book dealer. At least part of the collection once sat on the shelves of the Society of Advocates Library in Aberdeen. The documents belonged to at least two different men: William Craig, Lord Craig (17451813), an advocate and later judge on the Court of Session, and

\footnotetext{
${ }^{1}$ Readers may access SCOS at http://scos.law.virginia.edu/.The title quote is from " 2 February 1776" in James Boswell, Boswell's Edinburgh Journals, 1767-1786, ed. Hugh M. Milne (Edinburgh: Mercat Press, 2001), 238. For a more comprehensive exploration of SCOS, Session Papers, and the Court of Session, see James P. Ambuske, Randall Flaherty and Loren S. Moulds, "Recovering Hidden Histories of Early America and the British Atlantic World with the Scottish Court of Session Digital Archive Project," Scottish Archives: The Journal of the Scottish Records Association 24 (2018): 26-42; James P. Ambuske, "Session Papers and the British Atlantic World," The Scottish Court of Session Digital Archive Project, accessed 19 December 2019, http://scos.law.virginia.edu/scholarship/windows.
} 
Andrew Skene (1784-1835), an advocate and briefly Scotland's solicitor general. ${ }^{2}$ Unlike the thickly bound volumes of Session Papers held by the Faculty of Advocates Library, the Society of the Writers to the Signet Library, or the Centre for Research Collections (CRC) at the University of Edinburgh, the documents in the UVA Law Library's collection were disbound sometime in the past. The reasons for this dismemberment are unclear, although a few volumes do survive intact. Fortunately, the assailant separated the documents by case, which ironically makes it easier for twentyfirst century researchers to identify specific litigation and digitize the documents.

Achieving the project's goal of making Session Papers widely available for new research and teaching opportunities means reckoning with their intended purpose for the making of Scots law. Session Papers were never meant for general public consumption. In 1710, the Court of Session ordered litigants to submit legal briefs, evidence, and other case materials in printed form. Copying manuscripts by hand risked introducing errors into legal proceedings in which precision mattered. Theoretically, printing Session Papers produced a uniform set of documents for distribution to the relevant parties. In other words, printing helped to ensure that everyone was on the same legal page. Appellant cases heard by the full court's Inner House generated the vast majority of surviving Session Papers,

${ }^{2}$ Craig and Skene's handwriting and signatures appear on a number of Session Papers in the UVA Law Library's collection. Recent investigations of documents from the 1790s suggests that a portion of the collection may have also belonged to Matthew Ross, of Candie (17501823). See their individual entries on SCOS: (Craig),

http://scos.law.virginia.edu/explore/people-organizations/william-craiglord-craig\%28787\%29; (Skene),

http://scos.law.virginia.edu/explore/people-organizations/andrewskene $\% 2846431 \% 29$; and (Ross).

http://scos.law.virginia.edu/explore/people-organizations/matthew-rosscandie $\% 2828041 \% 29$. 
including nearly 25,000 quarto pages of printed material in 1789 alone. The judges and legal counsel involved in a case received copies, as did the Advocates Library and the Signet Library. Men like Craig, Skene, and James Boswell assembled curated personal collections, keeping the cases they participated in and others they considered significant. The Advocates and Signet libraries sought to collect copies of each case that came before the court. Many documents feature extensive marginalia representing an individual's engagement with a case's facts and legal arguments, or a librarian's attempt to catalogue them. Occasionally, marginal notations reveal how the court ruled. The judges delivered decisions orally, which advocates sometimes recorded on their Session Papers. Unless a decision appeared in a published case report or legal digest, something not guaranteed given that civil law societies like Scotland placed significantly less importance on judicial precedent than common law countries such as England, marginalia on Session Papers might represent the only surviving record of the court's judgement. ${ }^{3}$

What can (largely) uncatalogued Scots law documents, complete with formulaic titles and filled with commentaries on the Justinian Code or Acts of Parliament, reveal about life in

3 "Act of Sederunt Anent Subscriving Informations, Petitions and Answers, 19 December 1710," in The Acts of Sederunt of the Lords of Council and Session, from the 1628 to 1740, Copied from the Books of Sederunt (Edinburgh, 1740), 214; John Finlay, "The Petition in the Court of Session in early modern Scotland," Parliaments, Estates and Representation 38 (2018): 337-49, https://doi.org/10.1080/02606755.2018.1532976; Angus Stewart, "The Session Papers in the Advocates Library," in Miscellany Four by Various Authors ed. H.L. MacQueen (Edinburgh: Stair Society, 2002), 199-224; James Hamilton, "The Archive of the Society of Writers to the Signet at the Signet Library, Edinburgh," Scottish Archives: The Journal of the Scottish Records Association 21 (2015): 114-15, https://www.scottishrecordsassociation.org/2282.Scottish $\% 20$ Archives $\% 2$ 0-21.10\%20Hamilton.web.2017-02-02.pdf. 
Scotland and the British Atlantic world? ${ }^{4}$ Quite a lot, actually. As civil court records, Session Papers offer a social, economic, and political portrait of the British Atlantic in the eighteenth and nineteenth centuries. The documents, which can include printed evidence such as extracted correspondence, account books, ship logs, and even maps, offer a wealth of information about the people who inhabited or engaged with Scotland in this period. ${ }^{5}$

\footnotetext{
${ }^{4}$ Repositories with major Session Papers collections include: The Faculty of Advocates Library (Edinburgh); The Writers to the Society of the Signet Library (Edinburgh); Centre for Research Collections, University of Edinburgh (Edinburgh); The Beinecke Rare Book \& Manuscript Library, Yale University (New Haven, CT); The Firestone Library, Princeton University (Princeton, NJ); The Huntington Library, (San Marino, CA); The Library of Congress (Washington, D.C.); and The Wolf Law Library, College of William and Mary (Williamsburg, VA). The vast majority of Session Papers are catalogued at the major collection level only, while some smaller collections do have item level description. One of the most comprehensive catalogues (with an index) to date was published during World War I. See Alexander Mill, Index to the Session Papers in the Signet Library, 1730-1820, 4 vols. (Edinburgh: Privately printed by the Signet Library, 1916-18), https://archive.org/search.php?query=creator\%3A\%22WS+Society $\% 22$. ${ }^{5}$ For examples of these evidence types, see James Wolfe Murray, Lord Cringletie, "Defender's Appendix to Record, in Process, Hugh Rose, Esq. of Glastullich, Against The Representatives of Kenneth M'Leay of Newmore," 24 Nov 1829, http://scos.law.virginia.edu/node/70451; [Unclear], "Accompt of Expences Incurred by John Phillips, Merchant in Glasgow, Defender, in the Process of Declarator at the Instance of the Late John Craig, Baker in Glasgow, Against Him, Afterwards Insisted by Robrt Criag, His Son ," 6 Jul 1791, http://scos.law.virginia.edu/node/75321; John Dillon, "Extract from the Log-Book-of the Ship La Gloire, Printed by Order of the Court, on Advising a Petition for Allan Bogle and Others, Underwriters on the Said Ship; Against Potts, Cook and Potts, Merchants, London," 5 Jun 1807, http://scos.law.virginia.edu/node/71961; John Watts, "Sketch from John Watts Map of the Firth of Clyde $[45 \mathrm{~cm}$ x $28 \mathrm{~cm}$. Appended to Petition of John Douglas, Merchant in Glasgow]," 1772, http://scos.law.virginia.edu/node/71366. These and the cases or documents
} 
Session Papers testify to the lives of individuals both ordinary and powerful. They include brief glimpses of people like John Moffat, a sixty-nine year-old bleacher and former resident of Carmyle, who gave a deposition in 1777 as part of dispute over water rights, or deeper insights into the private lives of people like Dumfries residents Agnes and George Mortimer, whose letters tell the story of their troubled marriage. They reveal how noblemen such as Alexander, fourth Duke of Gordon, claimed title to land confiscated by the crown following the 1745 Jacobite Uprising, as well as how the young sisters Elizabeth and Barbara Cunningham defended their interest in their late father's slave-powered Maryland tobacco firm. They demonstrate how James Graham, a formerly enslaved man, resisted impressment into the Royal Navy. Using Session Papers, we can reconstruct individual lives, whole communities, and the historical context in which they lived. ${ }^{6}$

SCOS strives to make Session Papers both accessible and enticing through digital technology and scholarship. To accomplish these goals, the project team is pursuing two interrelated, collaborative strategies to provide users with copies of the documents and the context in which to interpret them.

cited below all appear in Scottish Court of Session Digital Archive Project. (Charlottesville: University of Virginia Law Library, 2015-19).

${ }^{6}$ For these cases, see Corbet $v$. Mackenzie (1780), http://scos.law.virginia.edu/scos/explore/cases/corbet-v-mackenzie; Mortimer v. Creightons (c. 1829), http://scos.law.virginia.edu/node/76271; Alexander, Duke of Gordon v. The Commissioners for Managing the Forfeited Estates Annexed to the Crown (1771), http://scos.law.virginia.edu/explore/cases/alexander-dukegordon-v-commissioners-managing-forfeited-estates-annexed-crown; Cunninghames v. Dougal (1776), http://scos.law.virginia.edu/scos/explore/cases/cunninghames-v-dougal; Stewart v. Graham (1782), http://scos.law.virginia.edu/scos/explore/cases/stewart-v-graham. 
First, the team developed a custom-designed database using Drupal, an open-source content management system, to organize the UVA Law Library's digitized Session Papers and accompanying metadata. ${ }^{7}$ The court case is the database's primary intellectual unit. Using case titles imported with permission from the British and Irish Legal Information Institute (BAILII), determined through marginalia, or assigned after conducting research, the team created 'case shells' for each identified case in the library's collection. ${ }^{8}$ Like flesh and muscles on a skeleton, all metadata relevant to each case are attached to these shells.

Completed case records appear as individual pages on the SCOS website. A case page features a number of elements, including legal, biographical, and spatial data. ${ }^{9}$ The project team designed this page to give users a holistic overview of a case. A case abstract provides researchers with a basic summary of the legal dispute at hand. A structured list of the people involved in the case features the names of the litigants, their counsel, judges who played a critical role in the proceedings, and other individuals mentioned in associated Session Papers. Short biographical statements indicate a person's relationship to the case. Selecting an individual's name opens a new page with additional biographical information about the person, the cases in which they were involved, and Session Papers they might have authored.

The team also worked with The Gazetteer of Scotland to import historic place names and geographic coordinates into the database, allowing the team to associate cases, individuals,

\footnotetext{
${ }^{7}$ Drupal, accessed 19 December 2019, https://www.drupal.org/.

${ }^{8}$ British and Irish Legal Information Institute, accessed 19 December 2019, https://www.bailii.org/.

${ }^{9}$ See, for example, Mrs. Anne Nielson, \&c v. Austins (1767), http://scos.law.virginia.edu/scos/explore/cases/mrs-anne-nielson-c-vaustins.
} 
and corporate bodies with specific places. ${ }^{10}$ These locations populate a digital map on each case page, allowing visitors to see the litigation's spatial dimensions. In instances when the court's decision appears in a law report or legal digest, the case page includes a citation and hyperlink to the publication. Session Papers appear as separate records listed below the map on each case page. Selecting a record opens a new webpage containing digital images of the document and associated bibliographic data. Finally, subject tags index each case by area of law.

Initially, the project team intended to host its Session Papers on the UVA Law Library servers and offer digital copies as downloadable PDF documents. Subjecting them to Optical Character Recognition (OCR) software would have made the PDFs fully text-searchable.

In 2017, however, the SCOS team shifted course in response to new collaborative opportunities and technological developments. The team began working with colleagues at the Centre for Research Collections (CRC) at the University of Edinburgh, who are heading up an initiative to digitize Session Papers located in various Edinburgh libraries. Given the size of the collections in Edinburgh, and the lack of any standard catalogue for these documents, the CRC team adopted a 'digitize first' strategy for its project. It is teaching computers how to identify key elements of the digitized documents such as titles, individuals' names, and locations. If successful, this will expedite the creation of a comprehensive catalogue and make Session Papers more accessible. As part of this process, the CRC team uses the International Image Interoperability Framework (IIIF), a new technology that makes it easier to display and distribute high-resolution images on the web. ${ }^{11}$ In

${ }^{10}$ Gazetteer for Scotland, accessed 19 December 2019, https://www.scottish-places.info/.

${ }^{11}$ International Image Interoperability Framework, accessed 19 December 2019, https://iiif.io/. 
light of these developments, the SCOS team made the decision to upload its digitized images to the CRC's IIIF server.

SCOS's Session Papers now live on servers in Scotland. This has two benefits. First, it enables the two teams to 're-unite' Session Papers in Edinburgh, allowing them to build a more complete digital archive and reassemble cases whose constituent parts were scattered across the Atlantic. IIIF will allow other scholars and the public to import the documents into their own digital projects. Second, it makes it possible to process the SCOS team's material through the CRC team's advanced machine-reading software. ${ }^{12}$ This will allow for far more efficient searching than standard OCR, permitting keyword searches across multiple high-resolution images and returning results down to the line on the page. This opens up a world of possibilities beyond producing a better catalogue. Imagine what we might learn about Scotland and the slave trade, the transformation of Highland clan society, or the evolution of Scots law by performing text mining or geospatial analyses on digitized Session Papers.

Second, the SCOS team created ways for researchers to explore Session Papers as historical artifacts and as sources for asking new historical questions. While SCOS does let patrons peruse the documents by repository and archival box, SCOS's mission is to drive new scholarship by asking researchers to see Session Papers and their content in different ways. Besides an extended introductory essay examining the history and role of Session Papers in the legal process, the SCOS team developed 'entry points' into documents' content. For example, the "People and Organizations" page indexes the individual people and corporate bodies identified to date in fully processed case records. Eventually, the "Legal Geography" page will feature a global map of all locations mentioned in SCOS's documents.

${ }^{12}$ Michael Bennett of the University of Edinburgh Library developed Whiiif - Word Highlighting (in) IIIF. The code is freely available on Bennett's GitHub page: https://github.com/mbennett-uoe/whiiif. 
The "Curated Themes" page does much of the interpretative heavy lifting by organizing case records into coherent historical themes. Based on a reading of current scholarship, and the documents themselves, the SCOS team designed the themes to inspire new research in a number of areas. "Jacobite Legacies," for example, features litigation stemming from the failed Jacobite uprisings. "The Church and Religion" includes disputes that arose in local parishes, especially highly personal battles between clergymen and their flock. "Women Litigants" encourages scholars to investigate questions of gender, power, and authority from the late eighteenth through the early nineteenth centuries through the eyes of women who were the primary litigants in lawsuits. "Scottish Virginia" examines the commercial and familial links between Scotland and Britain's former colony in the era of the American Revolution. Lastly, cases in "Elections" address local and parliamentary contests, revealing candidates' machinations, and often the names of the men who voted for them. ${ }^{13}$

SCOS is an on-going project that welcomes new individual and institutional partnerships. ${ }^{14}$ By working collaboratively, we can resolve common technical and bibliographic challenges that will increase access to Session Papers and the rich histories they contain. Scots and numerous other litigants in the British Atlantic world pursued civil justice before the Court of Session in the eighteenth and nineteenth centuries. Their voices lie hidden in obscure legal documents. Through a combination of technology and research, we can hear them again.

\footnotetext{
${ }^{13}$ For the entry points, please see http://scos.law.virginia.edu/scos/explore.

${ }^{14}$ Please contact SCOS' project directors (James P. Ambuske, Randall Flaherty, and Loren Moulds) if you would like to discuss potential collaborations. Ambuske can be reached directly at jambuske@mountvernon.org
} 